\title{
PENGARUH PEMBERIAN RAGI TAPE PADA TEPUNG UBI JALAR DALAM PAKAN TERHADAP PERSENTASE KARKAS DAN BERAT LEMAK ABDOMINAL AYAM BROILER
}

\author{
Klaudius Busa; Permata Ika Hidayati; Enike Dwi Kusumawati \\ Fakultas Peternakan, Universitas Kanjuruhan Malang, \\ Jl. S. Supriadi No.48 Malang \\ Email: permata@unikama.ac.id
}

\begin{abstract}
This research was conducted at the Faculty of Animal Husbandry Field Laboratory Kanjuruhan Malang began in March 2016 to april 2016. The material used is 100 broiler chickens aged 1 day. The purpose of this study was to determine the effect of yeast tape on potato epung jalardalam feed on carcass percentage and abdominal fat weight. The method used is experiment with completely randomized design (CRD) using 6 treatments and each treatment was repeated 3 times. The treatments used in this study are basal feed without the addition of sweet potato flour (P0) and the basal feed given the addition of sweet potato flour 1.5\% (P1), $23 \%(\mathrm{P} 2), 4.5 \%(\mathrm{P} 3), 5$ , 4\% (P4), 6\% (P5), $7.5 \%$ (P6). The results showed the addition of sweet potato starch flour give effect to the percentage of carcass and abdominal fat weight in all treatments.
\end{abstract}

Key words: percentage of carcass weight and abdominal fat

\begin{abstract}
Abstrak
Penelitian ini dilaksanakan di Laboratorium Lapang Fakultas Peternakan Universitas Kanjuruhan Malang mulai bulan maret 2016 sampai bulan april 2016. Materi yang digunakan adalah 100 ekor ayam broiler yang berumur 1 hari. Tujuan penelitian ini adalah untuk mengetahui pengaruh pemberian ragi tape pada epung ubi jalardalam pakan terhadap presentase karkas dan berat lemak abdominal. Metode penelitian yang digunakan adalah percobaan dengan Rancangan Acak Lengkap (RAL) dengan menggunakan 6 perlakuan dan setiap perlakuan diulang sebanyak 3 kali. Perlakuan yang digunakan dalam penelitian ini yaitu pakan basal tanpa penambahan tepung ubi jalar (P0) dan pakan basal yang diberikan penambahan tepung ubi jalar 1,5\% (P1), 2 3\% (P2), 4,5\% (P3),5,4\% (P4),6\% (P5),7,5\% (P6). Hasil penelitian menunjukkan penambahan tepung tepung ubi jalar memberikan pengaruh terhadap presentase karkas dan berat lemak abdominal pada semua perlakuan.
\end{abstract}

Kata kunci : presentase karkas dan berat lemak abdominal

\section{Pendahuluan}

Populasi ternak ayam broiler selalu mengalami peningkatan, yaitu 986.872.000 ekor pada tahun 2010, 1.177.991.000 ekor pada tahun 2011, 1.244.402.000 ekor pada tahun 2012, dan 1.355.288.000 ekor pada tahun 2013 (Badan Pusat Statistik, 2014). Konsumsi daging ayam di Indonesia relatif lebih tinggi dari pada daging sapi, kambing, ataupun babi. Daging ayam mengandung sedikit lemak dan kaya protein (Priyatno, 2000).

Saat ini peternakan ayam broiler memiliki prospek usaha yang menjanjikan di Indonesia, mengingat kebutuhan protein asal hewani dari tahun ke tahun mengalami peningkatan. Menurut Bahri et al. (2005) protein hewani tersusun dari asam-asam amino yang mudah didegradasi oleh tubuh, bersifat esensial bagi perkembangan dan pertumbuhan tubuh manusia. Kebutuhan konsumsi protein hewani (daging) masyarakat 


\section{Jurnal Sains Peternakan}

Vol 6 No 2, Desember 2018, 24-33

ISSN 2579-4450

mengalami peningkatan setiap tahunnya dari 3,41 g per kapita pada tahun 2012 dan 3,64 g per kapita tahun 2013 (BPS Peternakan, 2014). Peningkatan perkembangan industri peternakan ayam broiler tidak pernah lepas dari aspek pakan. Biaya pakan sendiri merupakan $70 \%$ biaya produksi ayam broiler, maka pakan yang diberikan ke ayam harus berkualitas dan memenuhi nutrien yang dibutuhkan oleh ayam tersebut dengan tujuan menghasilkan produk yang diinginkan.

Nutrien utama yang dibutuhkan oleh ayam pada umumnya sama seperti yang dibutuhkan ternak lainnya, berupa karbohidrat, protein, lemak, vitamin dan mineral. Pakan yang mengandung nutrien berkualitas dapat menghasilkan performa yang optimal dan produktifitas maksimal. Peningkatan kualitas pada pabrik pakan umumnya dengan melakukan manipulasi komposisi pakan diantaranya dengan penambahan feed additive yang dicampurkan ke dalam pakan, feed additive yang digunakan dapat berupa antibiotik, probiotik, dan prebiotik. Feed additive berupa probiotik adalah suatu bahan yang mengandung koloni mikroba tertentu, yang digunakan dengan tujuan meningkatkan daya cerna ransum sehingga produktivitas ternak meningkat (Dutta et al., 2009). Keberadaan probiotik sendiri dapat berkembang lebih baik jika dikombinasikan dengan prebiotik, yang merupakan nutrien bagi probiotik. Menurut Ferket et al. (2007) ada beberapa mekanisme kerja probiotik sebagai growth promoter, yaitu dengan menjaga ekosistem serta menyediakan nutrien bagi inang tersebut, selain itu kegunaan dari probiotik dapatat menggantikan antibiotik yang sering digunakan sebagai feed additive.

Kombinasi probiotik dengan prebiotik yang diberikan secara bersamaan disebut sebagai sinbiotik. Beberapa jenis prebiotik yang popular termasuk dalam kelompok oligosakarida yaitu fruktosa, rafinosa, inulin, dan galaktosa. Salah satu jenis kelompok oligosakarida yang dapat dijadikan sebagai sumber prebiotik adalah kelompok gula sederhana seperti rafinosa, maltotriosa yang ditemukan pada ubi jalar. Kelompok oligosakarida seperti rafinosa, stakiosa, dan verbakosa tidak dapat dicerna oleh enzim dalam saluran pencernaan, sehingga memerlukan adanya bantuan mikroba pencerna dalam melakukan proses pencernaan senyawa tersebut, salah satu mikroba tersebut adalah Sacharomyces cervisiae asal ragi tape yang saat ini sering digunakan untuk fermentasi pati dari ubi kayu. Potensi ubi jalar dapat sebagai sumber prebiotik karena adanya senyawa rafinosa dan meltotriosa selain itu, juga ubi jalar dapat digunakan sebagai sumber karbohidrat diantara tanaman umbi-umbian lainnya. Badan Pusat Statistik (2011) menyatakan ubi jalar menduduki urutan kedua dengan produksinya 2.172.228 ton setelah singkong, sehingga keberadaan ubi jalar sendiri jumlahnya melimpah di Indonesia. Ubi jalar dipilih karena kandungan karbohidrat dan serat sebagai sumber prebiotik. Ubi jalar 
saat dipanen mempunyai berat kering 16\%-40\% dan 75\%-90\% adalah karbohidrat. Komponen utama karbohidrat yaitu pati (60\%-70\% amilopektin dan 30\%-40\% amilosa), dan serat pangan (sellulosa, hemisellulosa dan pentosa) serta beberapa jenis gula bersifat larut. Jenis oligosakarida ubi jalar adalah rafinosa sebagai oligosakarida tidak tercerna yang dapat menurunkan timbulnya penyakit kanker usus, hati dan saluran pencernaan (Palmer, 2006). Pemberian ubi jalar yang diolah menjadi tepung dengan penambahan ragi tape dalam ransum sebagai sumber sinbiotik diharapkan meningkatkan konsumsi pakan,pertambahanan bobot badan serta konversi pakan.

\section{Materi Dan Metode}

Kegiatan penelitian ini, dilakukan pada Maret sampai April 2016, penelitian dan pecampuran pakan dilaksanakan di Laboratorium Lapang Fakultas Peternakan Universitas Kanjuruhan Malang.

\subsection{Materi}

\section{Ternak}

Penelitian ini menggunakan 180 ekor ayam broiler umur tujuh hari strain CP 707 dari PT. Charoend Phokphand yang dibagi menjadi enam perlakuan dan tiga ulangan, dengan setiap ulangannya terdiri dari sepuluh ekor. Ayam dipelihara selama 28 hari sebelumnya dilakukan pemeliharaan selama tujuh hari. Sampel ayam yang diambil untuk mengukur pertambahan bobot badan adalah satu ekor untuk setiap ulangan.

\section{Ubi Jalar}

Tepung ubi jalar dibuat dengan memotong ubi menjadi ukuran tipis, kemudian di oven dengan suhu $60^{\circ} \mathrm{C}$ selama dua hari hingga kering selanjunya digiling hingga halus. Penggunaan tepung ubi jalar dengan dua level yaitu 3\% dan $6 \%$ dari total campuran ransum yang diberikan.

\section{Ragi Tape}

Ragi diperoleh dari toko beras yang berada di Pasar Dinoyo, dengan tujuan untuk mendapatkan produk ragi yang homogen dan kontuinitasnya terjamin. Ragi yang disediakan berbentuk kepingan, sehingga untuk menghaluskan dilakukan penggilingan. Penggunaan ragi dengan tiga level yaitu $0,5 \%, 1,0 \%$ dan $1,5 \%$ dari total campuran ransum.

\section{Pakan}

Ransum yang digunakan adalah ransum komersil ayam broiler berbentuk crumble, dibagi menjadi dua periode yaitu periode starter (umur 1-21 hari) menggunakan jenis ransum komersil BR1 Pokphand CP BR11 dan periode finisher (umur 22 hari- panen) 
menggunakah jenis BR2 Pokphand CP BR12. Penggunaan pakan komersil pada penelitian untuk melihat hasil dengan perlakuan penambahan probiotik dan prebiotik sebagai pengganti antibiotik yang umum digunakan oleh peternak. Komposisi pakan komersil broiler starter BR1 CP511 dan pakan komersil broiler finisher BR2 CP512 dari PT. Charoen Phokphand tersusun atas : jagung, dedak, bungkil kedelai, bungkil kelapa, tepung daging dan tulang, pecahan gandum, bungkil kacang tanah, tepung daun, kanola, kalsium, fosfor, vitamin, mineral, dan antioksidan.

\subsection{Metode}

\section{Pemeliharaan Ayam}

Tahap awal pelaksanaan penelitian, membersihkan kandang dan alat-alat yang akan dipakai, kandang diberi kapur, dan disemprot secara merata dengan desinfektan, setelah itu setiap petak kandang beralaskan koran dan di atasnya diberi sekam padi. Sekeliling kandang dilapisi dengan terpal sebagai pelindung untuk mengurangi pengaruh udara luar. Pemeriksaan terhadap lampu dan keran untuk menyediakan air minum dilakukan dua hari sebelum ayam datang. Kandang diberi tanda sesuai perlakuan yang diberikan. Setelah umur tiga minggu sampai lima minggu, tempat pakan dan minum digantung sejajar dengan punggung ayam agar pakan dan air minum tidak mudah kotor oleh ekskreta maupun sekam. Ayam broiler dipelihara selama 34 hari. DOC yang baru datang diberikan larutan gula sebagai sumber energi yang mudah diserap oleh saluran pencernaan ayam menggantikan energi yang hilang selama pengangkutan karena stres.

Ayam umur 0-7 hari diberikan ransum komersial periode starter dari PT. Charoen Phokphand BR1 CP511. Hari ke 7 ayam mulai diberikan ransum perlakuan. Penimbangan awal mulai diberikan ransum perlakuan umur 7 hari menggunakan timbangan digital dan hasilnya dicatat, kemudian dilakukan pengacakan ayam dan dimasukkan ke dalam kandang uji. Setiap kandang diisi oleh 10 ekor ayam. Lampu pijar berfungsi sebagai penerang yang dinyalakan pada saat menjelang malam. Tirai yang berfungsi sebagai pelindung dipasang setelah kandang disterilkan sehingga seluruh bagian kandang tertutupi sampai ayam berumur 14 hari dan hari berikutnya setiap pagi tirai dibuka setengah bagian dinding kandang dan ditutup saat menjelang malam hari untuk melindungi ayam dari udara dingin. Penambahan sekam tidak dilakukan secara teratur dan hanya pada alas sekam yang sudah basah karena feses ayam atau tumpahan air minum. 


\section{Perlakuan}

Penelitian ini menggunakan ransum ayam pedaging yang dicampur tepung ubi jalar dan ragi tape, yang dibedakan menjadi enam macam ransum perlakuan, dengan taraf tepung ubi jalar dan ragi tape yang berbeda-beda yaitu sebagai berikut:

$$
\begin{aligned}
& \mathrm{R} 1=\text { ransum komersil }+ \text { tepung ubi jalar } 3 \% \text { dan ragi 0,5\% } \\
& \mathrm{R} 2=\text { ransum komersil }+ \text { tepung ubi jalar } 3 \% \text { dan ragi 1,0 } \% \\
& \mathrm{R} 3=\text { ransum komersil + tepung ubi jalar } 3 \% \text { dan ragi 1,5\% } \\
& \mathrm{R} 4=\text { ransum komersil + tepung ubi jalar } 6 \% \text { dan ragi 0,5 } \% \\
& \mathrm{R} 5=\text { ransum komersil + tepung ubi jalar } 6 \% \text { dan ragi 1,0 } \% \\
& \mathrm{R} 6=\text { ransum komersil + tepung ubi jalar 6\% dan ragi 1,5\% }
\end{aligned}
$$

Rancangan yang digunakan adalah Rancangan Acak Lengkap (RAL) pola faktorial $2 \times 3$, faktor A terdiri dari dua perlakuan (Tepung ubi jalar: 3\% dan 6\%) dan faktor B terdiri tiga perlakuan (ragi : $0,5 \%, 1 \%$ dan1,5\%), tiap perlakuan terdiri dari tiga ulangan dan setiap ulangan terdiri dari 10 ekor ayam. Model matematika dari rancangan ini (Steel dan Torrie, 1993) adalah : Yijk $=\mu+\alpha i+\beta j+(\alpha \beta) i j+\varepsilon i j k$

Keterangan :

Yijk : Hasil pengamatan penggunaan tepung ubi jalar (prebiotik) dan ragi tape(probiotik) terhadap performa dan organ dalam ayam broiler umur minggu

$\mu \quad$ : Nilai rataan umum dari pengamatan

$\alpha \mathrm{i} \quad$ : Pengaruh perlakuan penambahan tepung ubi jalar (prebiotik)

$\beta \mathrm{i} \quad$ : Pengaruh perlakuan penambahan ragi tape (probiotik)

$(\alpha \beta)$ ij $\quad$ Interaksi penambahan tepung ubi jalar dengan ragi tape dalam ransum basal

Eijk : Galat akibat pengaruh perlakuan penambahan tepung ubi jalar (prebiotik) dan ragi tape (probiotik)

Data yang diperoleh dianalisis dengan sidik ragam (ANOVA, Analysis of Variance) dan jika berbeda nyata akan diuji lebih lanjut dengan Uji Jarak Duncan(Steel dan Torrie, 1993), sedangkan untuk data mortalitas dianalisa secara deskriptif.

\section{Data Yang Diamati}

Pesentase karkas ( gram / ekor ) \%

Presentase karkas diperoleh dari berat karkas dan berat hidup yang dihitung dengan formulasi sebagai berikut :

Presentase karkas $=\frac{\text { berat karkas }}{\text { berat hidup }} \times 100 \%$ 


\section{Lemak abdominal}

Lemak abdominal diperoleh dari berat lemak abdomen dan berat hidup. Hasil tersebut dihitung dengan formulasi sebagai berikut :

Persentase Lemak Abdominal $=\frac{\text { berat lemak abdomen }}{\text { berat hidup }} \times 100 \%$

\section{Hasil Dan Pembahasan}

\section{Presentase Karkas}

Karkas ayam merupakan ayam yang telah dikeluarkan jeroannya, kepala dipisahkan dengan leher hingga batas pemotongan dan kaki. Karkas ayam dibuat klasifikasinya berdasarkan bagian-bagian tubuh (Rasyaf, 2003). Selama proses pengolahan akan terjadi kehilangan berat hidup kurang lebih 1/3 bagian ( berat daging siap masak itu nantinya kurang lebih $2 / 3$ dari berat hidupnya) karena bulu, kaki, cakar, leher ,kepala, jeroan atau isi dalam dan ekor di pisah dari bagian daging tubuh dengan demikian daging siap masak itu hanya tinggal daging pada bagagian tambah dengan siap masak itu 75\% dari berat hidup ( Rasyaf, 2003). Rata-rata umur presentase karkas dengan $\mathrm{P} 1=3015, \mathrm{P} 2=3134, \mathrm{P} 3=3000, \mathrm{P} 4=2984, \mathrm{P} 5=2961$, dan $\mathrm{P} 6=3033$. Hal ini menunjukkan bahwa presentase karkas pada P2 memperlihatkan sebagai presentase yang baik atau unggul dengan presentase yang tertinggi dibandingkan dengan presentase karkas yang memiliki berat yang berbeda. Interaksi pemberian tepung ubi jalar merah ditambah ragi tape sebagai sinbiotik tidak memberikan pengaruh terhadap persentase karkas ayam broiler. Presentase karkas tidak banyak berpengaruh terhadap kualitas karkas namun penting pada penampilan ternak sebelum dipotong. Menurut Edawati (1997) karkas ayam terdiri dari daging dan tulang sedangkan daging 50-70\% dari bobot karkas atau kurang lebih $\quad 40 \%$ dari bobot hidup. Bagian-bagian karkas yang banyak diperdagangkan adalah bagian daging dada, paha, atas dan paha bawah yaitu sekitar 32\% dari bobot total karkas dan mempunyai harga yang lebih tinggi, sedangkan bagian karkas yang banyak mengandung tulang terdapat didaerah punggung, leher dan sayap yaitu sekitar 30\% dan jeroan (hati, jantung dan ampela) sekitar 7\% kemudian di imbangi oleh bagian-bagian lainnya. Faktor-faktor yang mempengaruhi presentase bobot karkas meliputi jenis kelamin, bobot badan, dan umur. Persentase bobot karkas ayam broiler jantan lebih tinggi di bandingkan dengan presentase bobot karkas ayam betina ( Brake at al., 1993). Gray at al (1982), menambahkan bahwa faktor-faktor yang mempengaruhi bobot karkas tidak hanya jenis kelamin, umur dan bobot badan tetapi ada beberapa faktor-faktor yang dapat mempengaruhi karkas diantaranya strain, makanan, 


\section{Jurnal Sains Peternakan}

Vol 6 No 2, Desember 2018, 24-33

ISSN 2579-4450

manajemen, dan lingkungan. Kualitas karkas dan daging dipengaruhi oleh factor sebelum dan setelah pemotongan. Faktor sebelum pemotongan yang dapat mempengaruhi kualitas daging antara lain: genetic, spesies, bangsa, tipe ternak, jenis kelamin, umur, pakan termasuk bahan aditif (hormon, antibiotic atau mineral) dan stress. Faktor setelah pemotongan meliputi pelayuan, stimulasi listrik, metode pemasakan, $\mathrm{pH}$ karkas dan daging, bahan tambahan termasuk enzim pengempuk daging, hormone dan antibiotic, lemak intramuskuler atau marbling, metode penyimpanan dan preservasi, macam otot daging dan lokasi pada suatu otot daging. Didalam bangsa ternak yang sama, komposisi karkas dapat berbeda. Bangsa ternak dapat menghasilkan karkas dengan karasteristiknya sendiri. Perbedaan komposisi tubuh dan karkas diantaranya bangsa ternak, terutama disebabkan perbedaan ukuran tubuh dewasa atau perbedaan berat pada saat dewasa.. Faktor lingkungan dapat dibagi menjadi dua kategori yaitu fisiologi dan nutrisi. Umur, berat hidup dan kadar laju pertumbuhan juga mempengaruhi komposisi karkas. Proporsi tulang, otot, dan lemak sebagai komponen utama karkas dipengaruhi oleh faktor-faktor tersebut diatas. Bila proporsi suatu variabel tinggi, maka proporsi salah satu variabel kedua/ lainnya lebih rendah. Pertambahan bobot badan merupakan salah satu kriteria yang digunakan untuk mengukur pertumbuhan. Pertambahan bobot badan diperoleh melalui pengukuran kenaikan bobot badan dengan melakukan penimbangan berulang-ulang dalam waktu tiap hari, tiap minggu atau tiap bulan. Kecepatan pertumbuhan mempunyai variasi yang cukup besar, keadaan ini bergantung pada tipe ayam, jenis kelamin, galur, tata laksana, temperatur lingkungan, tempat ayam tersebut dipelihara serta kualitas, dan kuantitas makanan. Pada masa pertumbuhan, ayam harus memperoleh makanan yang banyak mengandung protein, zat ini berfungsi sebagai pembangun, pengganti sel yang rusak dan berguna untuk pembentukan telur. Kebutuhan protein perhari ayam sedang bertumbuh dibagi menjadi tiga bentuk kebutuhan yaitu protein yang dibutuhkan untuk pertumbuhan jaringan, protein untuk hidup pokok dan protein untuk pertumbuhan bulu. Keseimbangan zat-zat nutrisi, terutama imbangan energi dan protein penting karena nyata mempengaruhi pertumbuhan. Pada umumnya semua ternak unggas, khususnya ayam broiler termasuk golongan yang memiliki pertumbuhan cepat. Pertumbuhan ayam pedaging sengat cepat dan pertumbuhan dimulai sejak menetas sampai umur 8 minggu, setelah itu kecepatan pertumbuhan akan menurun.

\section{Lemak Abdominal}

Lemak abdominal pada karkas ayam broiler menentukan kualitas daging ayam broiler seperti yang dikatakan Mihardja (1981) yaitu, deposisi lemak pada areal 


\section{Jurnal Sains Peternakan}

Vol 6 No 2, Desember 2018, 24-33

ISSN 2579-4450

abdominal merupakan hal yang tidak menguntungkan karena dapat menimbulkan masalah yaitu kolesterol yang dapat mengganggu kesehatan. Kemudian, Rose (1997) menyatakan bahwa, lemak tubuh akan meningkat seiring dengan mendekatinya masa dewasa ukuran tubuh. Semakin dewasa, lemak di dalam tubuh ayam akan semakin meningkat. Rata-rata umur berat lemak abdominal dengan P1 $=69, \mathrm{P} 2=75, \mathrm{P} 3=70, \mathrm{P} 4$ $=72, \mathrm{P} 5=70$, dan P6 = 77. Hal ini menunjukkan bahwa berat lemak abdominal pada P6 memperlihatkan sebagai berat yang baik atau unggul dengan berat yang tertinggi dibandingkan dengan berat lemak abdominal yang memiliki berat yang berbeda. Interaksi pemberian tepung ubi jalar merah ditambah ragi tape sebagai sinbiotik tidak memberikan pengaruh terhadap persentase bobot rempela ayam broiler. Tujuan dari pemberian perlakuan adalah untuk memberikan tingkat konsumsi yang optimum terhadap kalori dan protein dengan harapan daging yang dihasilkan tidak berkurang, malah lebih meningkat baik kuantitas maupun kualitasnya serta tidak menyebabkan terjadinya penimbnunan lemak tubuh terutama lemak abdominal. Karena lemak tersebut dikaitkan dengan aspek yang merugikan antara lain pemborosan energy, mengalami perubahan berat setellah prossesing, banyak yang hilang pada saat pada saat dimasak dan kolestrol dapat mengganggu kesehatan. Dikatakan pula, biasanya berat lemak abdominal berkisar 2-2,5\% dari berat karkas, bahkan dapat mencapai 5-6\%, lemak di timbun dalam tiga bagian pertama dalam rongga abdomen terutama sekeliling tembolo, kedua pada kulit terutama pada pangkal bulu dan pada bagian belakang dekat pangkal ekor dan ketiga pada organ tubuh lainnya (Waksito, 1981). Soeharsono (1976) menyatakan, penimbunan lemak abdominal merupakan penghamburan energi dan merugikan berat karkas, lemak itu sendiri akhirnya di buang waktu pengolahan (persyaratan komersil). Kadar lemak bebas abdominal maupun lemak keseluruhan, sangat lebih tinggi pada broiler yang diberi ransum dengan tingkat energi tinggi. Setelah ditinjau dari segi kualitas, tingkat energi $3200 \mathrm{kkal} / \mathrm{kg}$ ternyata menimbulkan timbunan lemak (lemak dan tubuh) yang sangat nyata lebih tinggi dan dan merugikan mutu karkas.

\section{Kesimpulan}

Berdasarkan Hasil Penelitian dapat disimpulkan bahwa pemberian terbaik secara statistik maupun numerik hasil penelitian menunjukkan bahwa presentase karkas terdapat pada P2, berat lemak abdominal terdapat pada P6, masing-masing memperlihatkan sebagai berat yang baik atau unggul dengan berat yang tertinggi dibandingkan dengan lemak abdominal yang memiliki berat yang berbeda. 


\section{Ucapan Terimakasih}

Ucapan terima kasih disampaikan kepada semua pihak terutama Laboratorium Lapang Fakultas Peternakan Universitas Kanjuruhan Malang yang telah banyak membantu sejak persiapan hingga terselenggaranya penelitian ini dengan baik.

\section{Daftar Pustaka}

Aini, N. 2004. Pengolahan tepung ubi jalar dan produknya untuk pemberdayaan ekonomi mayarakat pedesaan. Pasca Sarjana Intitut Pertanian Bogo, Bogor.

Amrullah, I. K. 2004. Nutrisi Ayam Broiler. Cetakan ke-II. Lembaga Satu Gunungbudi, Bogor.

Anwar, F. B. Setiawan, \& A. Sulaiman, 2001. Studi Karateristik Fisiko Kimia Dan Fungsional Pati Pada Tepung Ubi Jalar Serta Pemanfaatannya Dalam Rangkah Diversifikasi Pangan. PAU Pangan Dan Gizi. Institut Pertanian Bogor, Bogor.

Badan Pusat statistik. 2011. Statistik indonesia 2011, Jakarta. Indonesia

Bahri S, Masbulan E, Kusumaningsih A. 2005. Proses praproduksi sebagai faktor penting dalam menghasilkan produk ternak yang aman untuk manusia. J. Litbang Pertanian 24:27-35.

Caharoen Pokphand. 2005. Charoen Phokphan Broiler Breeder Guide Principles. (tidak diterbitkan).

Damardjati, D. S., Marwoto, D. K. S. Swastika D. M. Arsyad, dan Y. Hilman. 2005. Prospek dan Arah pengembangan Agribisnis Kedelai. Badan Litbang Pertanian, Departemen Pertanian. Jakarta.

Gray, et. al. 1995. Corporate Social and Environmental Reporting: A Review of Literature and a Longitudinal Study of UK Disclosure. Accounting, Audiitng, and Accountability Journal, Vol.8 No 2: 47-76.

Martono Adi Priyatno, (2000). Mendirikan usaha pemotongan ayam. Jakarta : Penebar Swadaya Pengukuhan Guru Besar Dalam Imlu Ternak. Fakultas Peternakan Diponegoro, Semarang.

Hidayat, N., M. C. Padaga, dan S. Suhartini, 2006. Mikrobiologi Industri. Penerbit Andi, Yogyakarta.

North and Bell. 1990. Commercial Chicken Production Manual, New York

Nur hidayat, dkk. 2006. Mikrobiologi Industri. Yogyakarta: Andi Yogyakarta

Nur Aini, H. Dwiyanti, dan R. Setyawati. 2004. Tepung ubi jalar sebagai bahan baku pembuatan mie dengan suplementasi olahan kedelai dan variasi sumber pengemulsi. Jurnal Pembangunan Pedesaan. III (3): 195-204. 
Palmer,J.K. 1982. Carbohydrate in Sweet Potato. In R.L.Villareal and T.D Griggs (Eds.).The First Int. Symposium Asian Vegetable. Res. Dev. Center. Shanhua.

Rasyaf, M. 2005. Pengolahan Usaha Peternakan Ayam Broiler. Penebar Swadaya. Jakarta

Sudarmadji, Bambang Haryono dan Suhardi. 2003. Analisa Bahan Makanan dan Pertanian. Kanisius. Yogyakarta.

Winarno, F.G. 2002. Kimia Pangan dan Gizi. Gramedia Pustaka Utama. Jakarta.

Winarno, F.G. dan Laksmi. 1973. Pigmen dalam Pengolahan Pangan. Departemen Teknologi Hasil Pertanian. Fakultas Teknologi Pangan dan Mekanisasi Pertanian IPB Bogor. Bogor:22-23.

Winarno, F.G., Srikandi F dan Dedi F. 1980. Pengantar Teknologi Pangan. Gramedia. Jakarta. 